\title{
FLORA DA RESERVA BIOLÓGICA GUARIBAS, PARAÍBA: MELASTOMATACEAE
}

\author{
FLORA OF THE GUARIBAS BIOLOGICAL RESERVE, PARAÍBA: MELASTOMATACEAE
}

\author{
Cínthia Menezes Lima Ramos Araújo ${ }^{1}$ \\ Earl Celestino de Oliveira Chagas ${ }^{2}$ \\ Rita Baltazar de Lima $\dagger^{3}$ \\ Maria Regina de V. Barbosa ${ }^{4}$
}

\section{Resumo}

A Reserva Biológica Guaribas, que compreende 4029 ha, está localizada a cerca de 52 $\mathrm{km}$ ao norte de João Pessoa, Paraíba. Ela possui três áreas distintas e é composta por vegetação de floresta e savana. Este estudo centra-se nas Melastomataceae e trata 7 gêneros e 20 espécies que ocorrem em áreas florestais e na savana. Miconia é o gênero mais diverso com 10 espécies, seguido de Clidemia, com quatro, Pterolepis, com duas e Comolia, Marcetia, Nepsera e Trembleya com uma espécie cada. O trabalho inclui uma chave para identificação das espécies, descrições, comentários e ilustrações.

Palavras-chave: Melastomataceae; chave de identificação; lista de espécies.

\begin{abstract}
The Guaribas Biological Reserve, comprising 4029 ha, is located about $52 \mathrm{~km}$ north of João Pessoa, Paraíba. It has three distinct areas and is made up of Atlantic forest and savanna. This study focuses on the Melastomataceae and treats 7 genera and 20 species, occurring in forest or savanna. Miconia is the most diverse genus with 10 species, followed by Clidemia, with 4 species, Pterolepis with two species and Comolia, Marcetia, Nepsera and Trembleya with one species each. The work includes an identification key to the species, descriptions, remarks and illustrations.
\end{abstract}

Keywords: Melastomataceae; identification key; list of species.

1 Programa de Pós-Graduação em Biologia Vegetal, Universidade Federal de Pernambuco, Cidade Universitária, 50670-901, Recife-PE. E-mail: cinthia.limaramos@gmail.com.

2 Programa de Pós-Graduação em Biologia Vegetal, Universidade Federal de Pernambuco, Cidade Universitária, 50670-901, Recife-PE. Herbário MAC, Departamento de Botânica, Instituto do Meio Ambiente do Estado de Alagoas, . Av. Major Cícero de Góes Monteiro, no 2197, Mutange, Maceió - AL. E-mail: earlchagas@gmail.com

3 Departamento de Sistemática e Ecologia, Universidade Federal da Paraíba, Cidade Universitária, 58051-90o, João Pessoa-PB.

† Falecida.

4 Programa de Pós-Graduação em Biologia Vegetal, Universidade Federal de Pernambuco, Cidade Universitária, 50670-901, Recife-PE. Departamento de Sistemática e Ecologia, Universidade Federal da Paraíba, Cidade Universitária, 58051-90o, João Pessoa-PB. E-mail: mregina@dse.ufpb.br 


\section{TRATAMENTO TAXONÔMICO DA FAMÍLIA NA REBIO GUARIBAS}

\section{Melastomataceae}

Ervas, subarbustos, arbustos ou árvores; ramos glabros ou pilosos, angulosos, cilíndricos ou compressos. Folhas opostas cruzadas, simples, acródromas, concolores ou discolores; sem estípulas. Inflorescências paniculiformes, dicasiais, glomerosas, espiciformes, por vezes com ramos secundifloros; flores bissexuadas, actinomorfas, diclamídeas, cálice (3-)4-(-5)-lobado, corola (3-)4-(-5)-mera; hipanto globoso, oblongo, campanulado, tubular ou urceolado; androceu diplostêmone; estigma punctiforme, ovário ínfero ou semi-ínfero, livre, parcial ou totalmente adnato ao hipanto. Fruto baga ou cápsula loculicida. Sementes numerosas, ovais ou cocleares.

\section{Chave para identificação das espécies}

1. Ervas; ramos com tricomas simples

2. Lamina foliar lanceolada; anteras amarelas com metade distal lilás. 18. Pterolepis glomerata

2'. Lâmina foliar ovada; anteras roxas ou lilases com ápice alvo.

\section{Pterolepis trichotoma}

1'. Subarbustos ou arbustos; ramos glabros ou pilosos, com tricomas de variados tipos

3. Ramos avermelhados ou ferrugíneos

4. Lâmina foliar e hipanto pilosos; lacínios oblongo-lanceolados, pétalas obovadas.

.5. Comolia villosa

4'. Lâmina foliar e hipanto glabros, lacínios triangulares ou linear-triangulares, pétalas elípticas

5. Ramos com tricomas simples; folhas pecioladas, lâminas ovadas a elípticas, 5-7 nervuras basais; hipanto globoso; pétalas alvas, anteras roxas com conectivo prol ongado.

..17. Nepsera aquatica

5. Ramos glabros; folhas sésseis, lâminas triquetas, 1 nervura basal; hipanto campanulado; pétalas lilases, anteras amarelas com conectivo não prolonga do 6. Marcetia ericoides

3'. Ramos nunca avermelhados nem ferrugíneos

6.Ramos hirsuto-glandulosos; anteras ovoide-oblongas; fruto cápsula..... 20. Trembleya phlogiformis

6'. Ramos com variados tipos de indumento; anteras subuladas, fruto baga 7. Lâmina foliar com 5-7 nervuras, face adaxial pilosa, margem denteado-ciliada 8. Ramos e folhas com tricomas ferrugíneos, pecíolo com até $0,2 \mathrm{~cm}$ compr

4. Clidemia sericea 
8'. Ramos e folhas com tricomas não ferrugíneos, pecíolo com mais de $0,2 \mathrm{~cm}$ compr.

9. Hipanto com tricomas glandulosos, lacínios externos deltóides 1. Clidemia biserrata

9'. Hipanto com tricomas nunca glandulosos, lacínios externos lineares

$\begin{aligned} & 10 . \\ & \text { Flvas................................................................................ 3. Clidemia hirta } \\ & \text { 10'. }\end{aligned}$ Folhas $\quad$ pubescentes, hipanto globoso; anteras
roxas........................................................................... 2. Clidemia debilis

7'. Lâmina foliar com 3-5-(-7) nervuras, face adaxial glabra, margem inteira, ondulado-crenulada, repanda ou denticulada

11. Panículas com ramos secundifloros.

12. Margem da lâmina foliar ciliada

9. Miconia ciliata

12'. Margem da lâmina foliar nunca ciliada

13. Lâmina com face abaxial glabra ou glabrescente .11. Miconia ferruginata

13'. Lâmina com face abaxial pubescente.

14. Anteras amarelas ou vermelhas, apêndice 1-lobado; frutos imaturos verdes, atropurpúreos na maturidade

......15. Miconia stenostachya

14'. Anteras brancas, apêndice inteiro ou 3-lobado; frutos imaturos róseos, verdes na maturidade.

15. Lâmina com base cordada; nervuras basais; ápice do estilete capitado. .7. Miconia albicans

15'. Lâmina com base aguda a atenuada; nervuras suprabasais; ápice do estilete clavado 14. Miconia serialis

11'. Panículas com ramos não secundifloros.

16. Lâmina com face abaxial completamente revestida por indumento.

17. Inflorescência ou infrutescência com ramos espiciformes; flores reunidas em glomérulos

8. Miconia amoena

17'. Inflorescência ou infrutescência com ramos dicasiais; flores reunidas em díades ou tríades 16. Miconia tomentosa

16'. Lâmina com face abaxial glabra ou glabrescente.

18. Lâmina decorrente no pecíolo; nervura suprabasal. 13. Miconia prasina

18'. Lâmina não decorrente no pecíolo; nervura basal.

19. Nervura central unida ao par interno por domácia .10. Miconia cuspidata

19'. Nervura central não unida ao par interno por domácia 12. Miconia minutiflora 

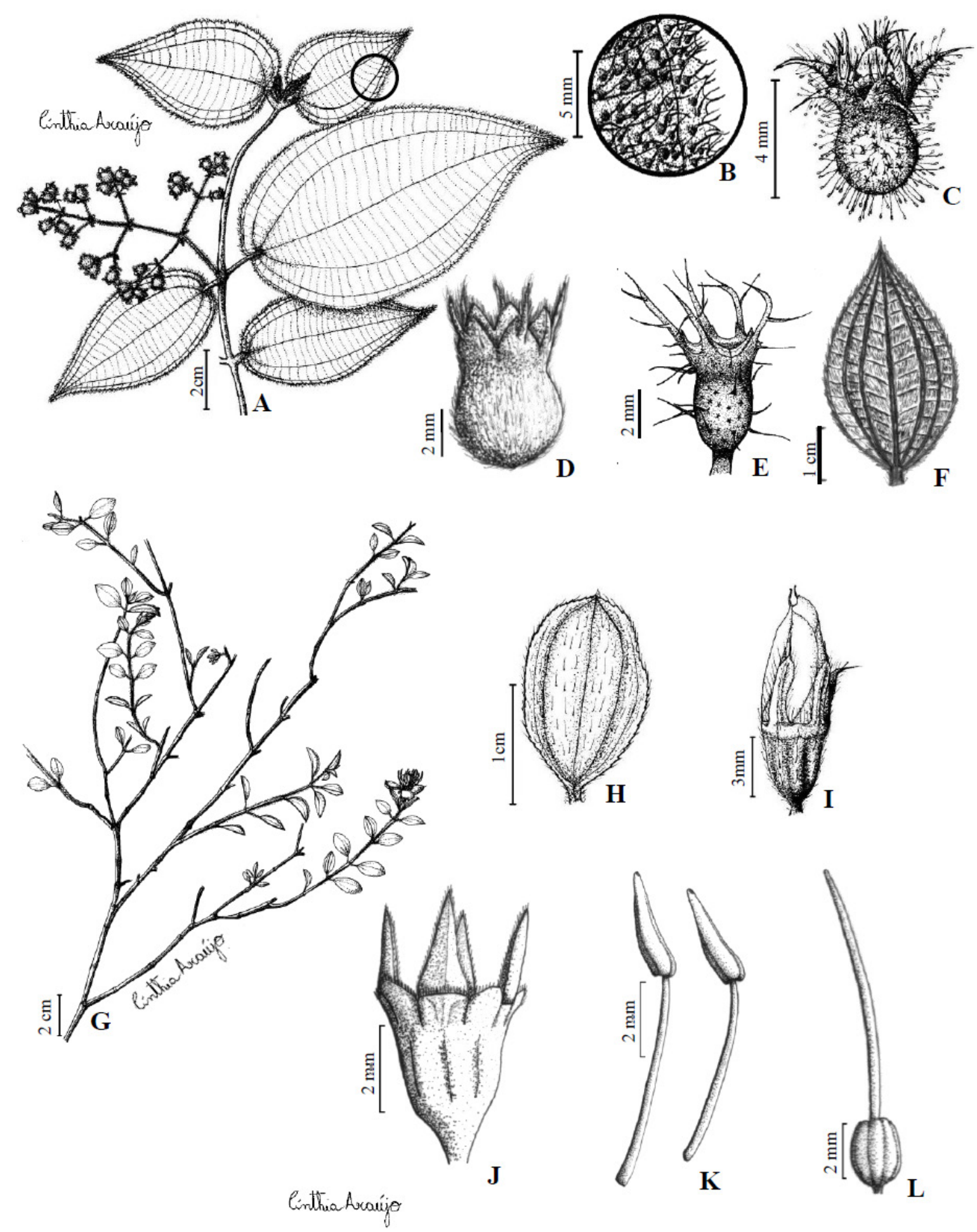

Fig. 1 A-C - Clidemia biserrata DC. A. Hábito; B. Detalhe da lâmina foliar, face adaxial; C. Cálice. D - C. debilis Crueg. D. Cálice. E - C. hirta (L.) D. Don. E. Cálice; F - C. sericea D. Don. F. Folha. G-I - Comolia villosa (Aubl.) Naudin. G. Hábito; H. Lâmina foliar, face adaxial; I. Botão floral. J-L - Marcetia ericoides (Spreng.) Berg. ex Cogn. J. Cálice; K. Estames; L. Gineceu. Ilustrações: Cínthia Araújo. 
1. Clidemia biserrata DC., Prodr. 3: 158. 1828.

(Fig. 1 A-C)

Arbusto, 1,3-1,5 m alt.; ramos cilíndricos; tricomas variados, glandulosos. Folhas pecioladas; pecíolo o,7-2,7 cm compr.; lâmina 5,7-13 x 2,7-8 cm, ovada, membranácea, ápice acuminado a cuspidado, margem denteado-ciliada, base cordada, face adaxial com tricomas simples e abaxial com tricomas estrelados; nervuras 5-7, as laterais confluentes, basais. Panícula, 6-9,5 x 3,5-7,5 cm, axilar. Flor 5-mera, pedicelo o,3-0,5 cm compr.; hipanto 3-3,2 x 2,5-3,1 mm, globoso, piloso-glanduloso; cálice persistente, lacínios externos 1,5-2 X 1,5-2 mm, deltoides, ápice aristado, os internos 1-1,3 X 1-1,5 mm, deltoides, ápice agudo; pétalas 3-4 x 2,4-3 mm, alvas, arredondadas a ligeiramente oblongas, glabras, ápice arredondado ou apiculado; estames-10, glabros; anteras 2-2,2 mm compr., poricidas, alvas, retas, conectivo sem apêndice; ovário ca. 2 x $2 \mathrm{~mm}$, 5-locular, ápice com tricomas glandulosos; estilete ca. 5,5 mm compr., glabro. Baga 5-7 mm compr., globosa, imatura verde, atroviolácea na maturação; sementes 0,5-0,7 mm compr., ovoides.

Material selecionado: BRASIL, Paraíba: Mamanguape, SEMA II, Cabeça de Boi, 6/III/1990, fl. e fr., L.P. Félix E E.S. Santana 2768 (JPB). Rio Tinto, SEMA III, Mata do Maracujá, 11/VI/1991, fr., L.P. Félix E C.A.B. Miranda 3894 (JPB).

Clidemia biserrata é uma espécie de ampla distribuição no Brasil (Michelangeli \& Reginato 2012). Em Guaribas a espécie ocorre em áreas florestadas. Caracteriza-se por apresentar ramos, folhas e hipanto com indumento variado e glanduloso.

2. Clidemia debilis Crueg., Linnaea 20: 104. 1847.

(Fig. 1 D)

Arbusto ca. $1 \mathrm{~m}$ alt.; ramos cilíndricos; tricomas simples, não glandulosos. Folhas pecioladas; pecíolo o,5-0,9 cm compr.; lâmina 6-8,5 x 3,5-4,8 cm, ovada a elíptica, membranácea, ápice agudo, margem denteado-ciliada, base obtusa, ambas as faces com tricomas simples; nervuras 5-7, as laterais confluentes, basais. Dicásio ou flores solitárias, axilares. Flor 5-mera, séssil; hipanto 4-4,5 x 4-4,3 mm, globoso, piloso; cálice persistente, lacínios externos 1,1-1,5 mm compr., lineares, ápice aristado, os internos ca. 1-1,5 X 0,9-1,5 mm, deltoides, ápice agudo; pétalas 2-2,3 X 1-1,2 mm, lilases, oblongas, piloso-lanuginosas, ápice obtuso; estames-8, glabros; anteras 2,5-2,9 mm compr., poricidas, roxas, retas; conectivo sem apêndice; ovário ca. 2,5 x 2,5 mm, 4-locular, ápice piloso, não glanduloso; estilete ca. $4 \mathrm{~mm}$ compr., glabro. Baga 5-7 mm compr., globosa, imatura vinácea, atroviolácea na maturação; sementes 0,7-0,9 mm compr., ovoides.

Material examinado: BRASIL, Paraíba: Mamanguape, Reserva Biológica Guaribas, SEMA II, 21/VII/2010, fl. e fr., R.A. Pontes et al. 491 (JPB). 
Clidemia debilis ocorre nas regiões Nordeste e Sudeste do Brasil (Michelangeli \& Reginato 2012). Na Rebio Guaribas foi encontrada em área florestada. Pode ser reconhecida por apresentar ramos, folhas e hipanto com tricomas simples, não glandulosos, e pelos estames com anteras roxas.

3. Clidemia hirta (L.) D. Don, Mem. Wern. Nat. Hist. Soc. 4(2): 309. 1823.

(Fig. 1 E)

Arbusto, 1,20-1,30 m alt.; ramos cilíndricos; tricomas simples, hirsutos, não glandulosos. Folhas pecioladas; pecíolo o,4-2,8 cm compr.; lâmina 3,5-11 x 2,5-8 cm, elíptica, ovada a sub-rotunda, membranácea, ápice cuspidado a acuminado, margem denteado-ciliada, base cordada, ambas as faces com tricomas simples; nervuras 5-7, as laterais confluentes, basais. Cimeira 2-2,5 x 1,5-3 cm, axilar. Flor 5-mera, pedicelo 2-5 mm compr.; hipanto 3,5-4 x 3-3,5 mm, urceolado, piloso, não glanduloso; cálice persistente, lacínios externos 2,5-3 mm compr., lineares, ápice aristado, internos ca. 1 x o,8 mm compr., deltoides, ápice agudo; pétalas 7,5 x 3,5 mm, alvas, oblongas a obovais, glabras, ápice obtuso; estames-10, glabros; anteras 4,1-4,5 mm compr., poricidas, alvas, retas; conectivo com apêndice dorsal ca. 0,5 mm compr.; ovário 4 x 1,8 mm, 5-locular, ápice glabro; estilete ca. $8 \mathrm{~mm}$ compr., glabro. Baga 6-9 mm compr., globosa, imatura verde, atroviolácea na maturação; sementes 0,4-0,5 mm compr., ovoides.

Material selecionado: BRASIL, Paraíba: Mamanguape, SEMA II, Área Florestal, 26/VII/2010, fl. e fr., R.A. Pontes et al. 494 (JPB). Rio Tinto, SEMA III, Mata do Maracujá, 23/V/1990, fl., L.P. Félix E E.S. Santana 3039 (JPB).

Clidemia hirta é uma espécie amplamente distribuída no Brasil (Michelangeli \& Reginato 2012). Em Guaribas ocorre nas áreas de floresta. É caracterizada por seus ramos, folhas e hipanto com tricomas hirsutos, hipanto urceolado, e flores maiores em relação a $C$. biserrata.

4. Clidemia sericea D. Don, Mem. Wern. Nat. Hist. Soc. 4(2): 310. 1823.

(Fig. 1 F)

Arbusto ca. 1 m alt.; ramos cilíndricos, tricomas simples, ferrugíneos, não glandulosos. Folhas pecioladas; pecíolo ca. o,2 cm compr.; lâmina 3,5-4 X 2-2,5 cm, ovada a elíptica, cartácea, ápice agudo, margem denteado-ciliada, base obtusa, ambas as faces densamente cobertas com tricomas simples; nervuras 5-7, as laterais confluentes, basais. Dicásio ou flores solitárias, axilares. Flor 4-mera, subséssil; hipanto $3 \times 2$ $\mathrm{mm}$, tubuloso, densamente seríceo; cálice persistente, lacínios externos ca. o,6 mm compr., subuladas, ápice agudo, internos ca. 1 x 1,5 mm compr., arredondados, ápice inconspícuo; pétalas ca. 2 x 1 mm, albo-róseas a magentas, oboval-oblongas, glabras, ápice arredondado a retuso; estames-8, glabros; anteras ca. $3 \mathrm{~mm}$ compr., poricidas, rubras, retas; conectivo sem apêndice; ovário ca. 2,5 x 1 mm, 3-locular, ápice setoso; 
estilete ca. $7 \mathrm{~mm}$ compr., glabro. Baga 4-7 mm compr., globosa, imatura verde, atroviolácea na maturação; sementes o,8-o,9 mm compr., ovoides.

Material examinado: BRASIL, Paraíba: Mamanguape, SEMA II, Capim Azul, 18/ VIII/1988, fr., L.P. Felix E C.A.B. Miranda 13 (JPB).

Clidemia sericea ocorre nas regiões Norte e Nordeste do Brasil (Michelangeli $\&$ Reginato 2012). Na reserva foi coletada na savana, onde o solo é mais arenoso. Pode ser reconhecida por apresentar pecíolo até $0.2 \mathrm{~mm}$ de comprimento e pelos ramos, folhas e hipanto com tricomas ferrugíneos. Este é o único registro da espécie para o estado da Paraíba. As informações sobre as flores de $C$. sericea foram baseadas em literatura específica (Matsumoto \& Martins 2005), por não ter sido encontrado, até o momento, exemplares férteis.

5. Comolia villosa (Aubl.) Triana, Trans. Linn. Soc. London 28(1): 37. 1871 (1872). (Fig.1 G-I)

Subarbusto 25-50 cm alt.; ramos angulosos, avermelhados; tricomas simples, glandulosos ou não. Folhas pecioladas; pecíolo 1-3 mm compr.; lâmina 0,9-2,4 X 0,51,8 cm, elíptica ou oboval, membranácea a cartácea, ápice agudo ou obtuso, margem serreado-ciliada, base aguda, ambas as faces com tricomas simples; nervuras 3-5, as laterais confluentes, basais. Dicásio axilar ou terminal. Flor 4-mera; pedicelo 1-2 mm compr.; hipanto 2,5-3,5 x 2-2,5 mm, oblongo, piloso, glanduloso ou não; cálice persistente, lacínios 2-4 x 1-1,5 mm, oblongo-lanceolados, ápice obtuso; pétalas 9-15 X 7-9 mm, lilases, obovadas, glabras, ápice arredondado a apiculado; estames-8, glabros; anteras 5-7 mm compr., poricidas, lilases, retas, conectivo o,5-0,9 mm compr. com apêndice ventral o,2-1 mm compr., bilobado; ovário 2,5-3 x 1,5-2 mm, 2-3-locular, ápice glabro; estilete $15 \mathrm{~mm}$ compr., glabro. Cápsula 3-7 mm compr., globosa ou oblonga, imatura verde, castanha na maturação; sementes o,2-0,5 mm compr., cocleares.

Material selecionado: BRASIL, Paraíba: Mamanguape, SEMA I, Caiana, 02/ II/2003, fl. e fr., M.R. Barbosa et al. 2611 (JPB); SEMA II, Lagoa dos Patos, Fontainha, 30/IV/2002, fl. e fr., M.R. Barbosa et al. 2450 (JPB).

Comolia villosa ocorre nas regiões Norte e Nordeste do país (Baumgratz 2012). Na ReBio Guaribas é encontrada nas savanas, onde o solo é arenoso. Caracteriza-se por apresentar ramos avermelhados, lacínios oblongo-lanceolados, cálice e androceu lilases. 
6. Marcetia ericoides (Spreng.) Berg. ex Cogn., Fl. Bras. 14(3): 456-457. 1885.

(Fig. $1 \mathrm{~J}-\mathrm{L}$ )

Subarbusto 16-30 cm alt.; ramos angulosos, ferrugíneos; glabros. Folhas sésseis; lâmina 0,3-0,5 x 0,09-0,11 cm, triqueta, coriácea, ápice agudo, margem serreadociliada, base truncada, ambas as faces glabras; nervura-1, obscura, basal. Flores solitárias 4-5-meras, terminais, pedicelo ca. $1 \mathrm{~mm}$ compr.; hipanto 2,8-3,5 x 2-2,5 $\mathrm{mm}$, campanulado, glabro; cálice ausente, lacínios 1,8-2,5 mm, linear-triangulares, serrulado-ciliados na margem; pétalas 6,9-7,5 x 4,5-5 mm, lilases, elípticas, glabras, ápice agudo; estames-8-10, glabros; anteras 2-3 mm compr., poricidas, amarelas, retas, conectivo não prolongado, espessado, com apêndice ventral curtamente bilobado; ovário 2,3 x 1,9 mm, 4-5-locular, glabro; estilete 7-9,5 mm compr., glabro. Cápsula ca. 3-5 mm compr., imatura vermelha, castanha na maturação; sementes ca. o,3 mm compr., cocleares.

Material examinado: BRASIL, Paraíba: Mamanguape, SEMA I, Capim Azul, 16/ VIII/1988, fl. e fr., L.P. Félix E C.A.B. Miranda 11 (JPB).

Material adicional examinado: BRASIL, Paraíba: Santa Rita, 20/VIII/1983, fl. e fr., M.F. Agra 461 (JPB); Usina São João, 10/XI/2011, fl. e fr., C.M.L.R. Araújo E R.A. Pontes 298 (JPB).

Marcetia ericoides ocorre na região Nordeste do Brasil (Martins \& Bernardo 2012) no Cerrado e na Mata Atlântica. Em Guaribas foi encontrada na savana, em solo arenoso, sazonalmente encharcado. Caracteriza-se pela lâmina foliar triqueta com apenas 1 nervura basal, hipanto campanulado e anteras amarelas. Este é o primeiro registro da espécie para a Paraíba. Segundo informações da Lista de Espécies da Flora do Brasil, a espécie ocorreria somente no estado da Bahia (Martins \& Bernardo 2012), no entanto, registros de herbário certificam que $M$. ericoides também ocorre nos tabuleiros costeiros presentes na porção norte da região Nordeste do Brasil. 

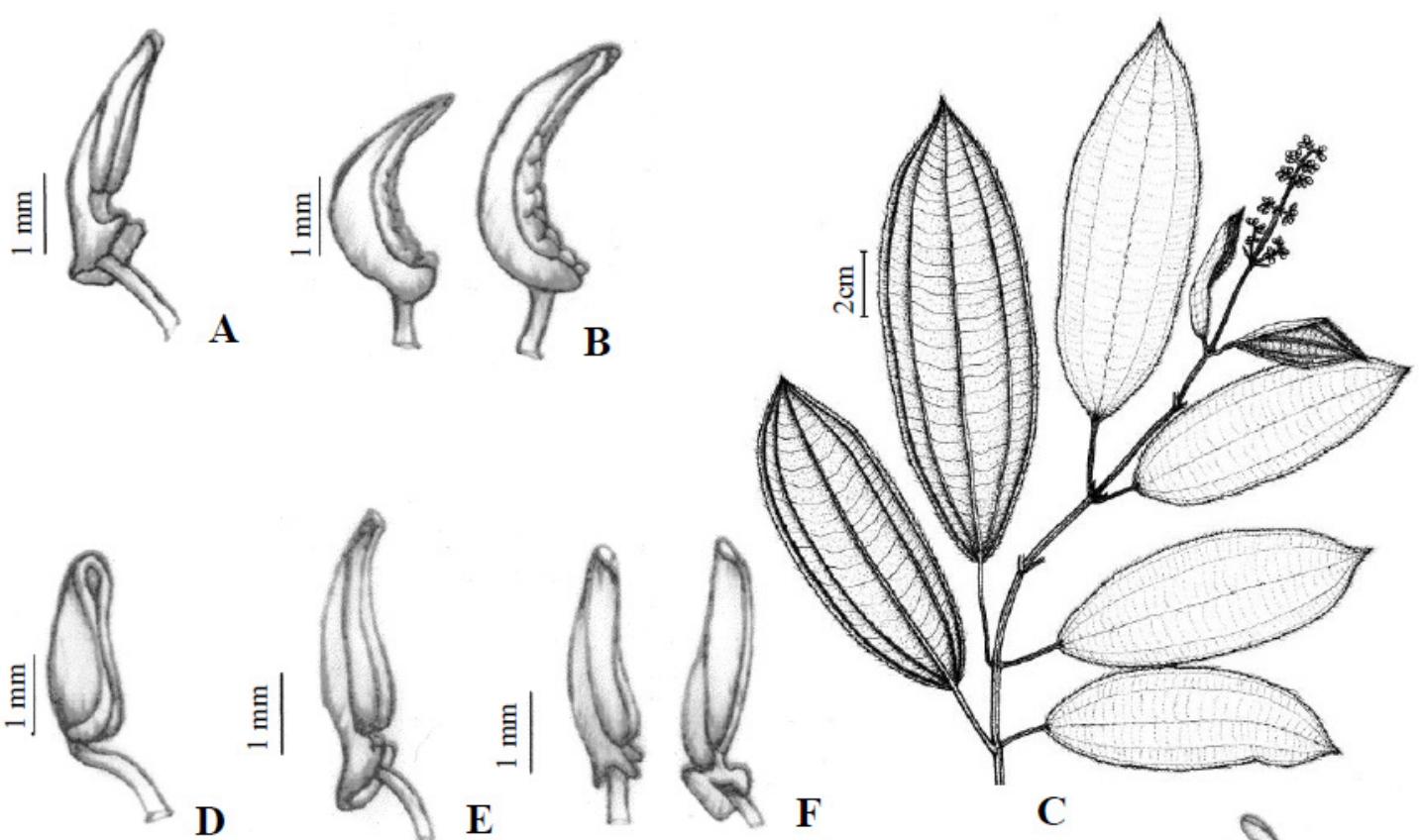

C
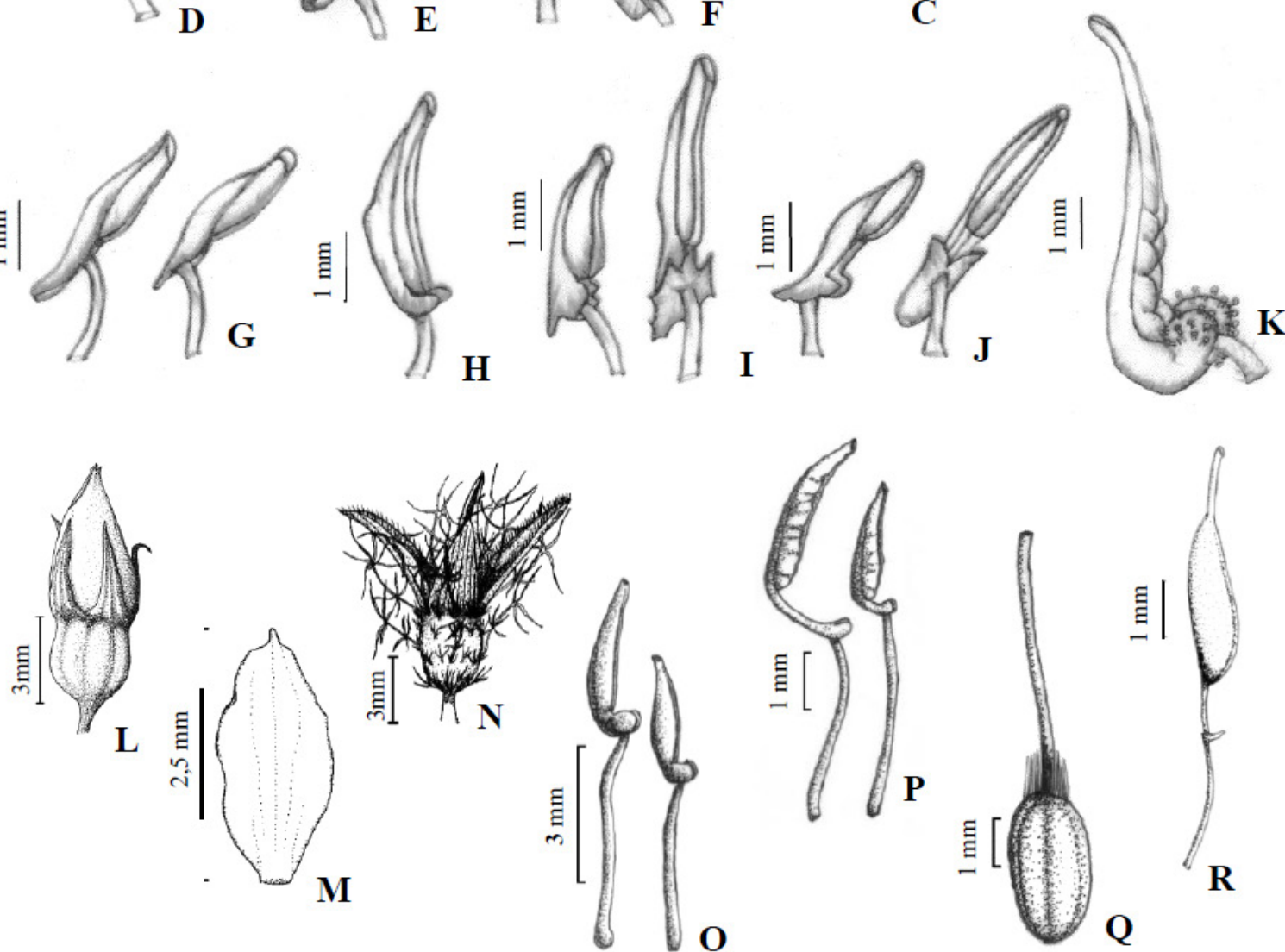

Fig. 2 - A-K - Hábito e anteras em Miconia. A. M. albicans (Sw.) Steud. - Antera. B. M. amoena Triana - Anteras. C-D. M. ciliata (Rich.) DC. - C. Ramo reprodutivo; D. Anteras.

E. M. cuspidata Naudin. - Antera. F. M. ferruginata DC. - Anteras. G. M. minutiflora (Bonpl.) DC. - Anteras. H. M. prasina (Sw.) DC. - Antera. I. M. serialis DC. - Anteras. J. M. stenostachya DC. - Anteras. K. M. tomentosa (Rich.) D.Don ex DC. - Antera. L-M. Nepsera aquatica Naudin. - L. Botão floral; M. Pétala. N-O - Pterolepis glomerata (Rottb.) Miq. - N. Cálice; O. Estames. P-Q - P. trichotoma (Rottb.) Cogn. - R - Trembleya phlogiformis DC. R. Estame. Ilustrações: A-B, D-K - Earl Chagas; C, L-R - Cínthia Araújo. 
7. Miconia albicans (Sw.) Steud., Nomencl. Bot. 2: 139. 1841.

(Fig. $2 \mathrm{~A}$ )

Arbusto 1,5-2 m alt.; ramos cilíndricos; tricomas aracnóides. Folhas sésseis ou pecioladas; pecíolo o,3-1 cm compr.; lâmina 6-15,3 x 3-5,5 cm, lanceolada a oblongoelíptica, cartácea a coriácea, ápice abruptamente agudo a aristado ou obtuso, margem ondulado-crenulada a inteira, base cordada, face adaxial glabra e abaxial densamente lanosa; nervuras 3-5, as laterais confluentes, basais. Panícula com ramos secundifloros, 6-14,2 cm compr., terminal. Flor 5-mera, séssil; hipanto 2,5$3 \mathrm{~mm}$ compr., campanulado; cálice persistente; pétalas 3-3,5 x 2-2,5 mm, alvas, orbiculares, glabras a glandular-ciliadas, ápice obtuso a emarginado; estames-10, glabros; anteras 2,5-4,5 mm compr., poricidas, alvas, retas, conectivo sem apêndice; ovário 1-2 mm compr., 3-locular, ápice papiloso; estilete 4-5 mm compr., glabro. Baga 3-6 mm compr., globosa, imatura rosa, verde na maturidade; sementes 1-1,5 mm compr., ovais.

Material selecionado: BRASIL. Paraíba: Mamanguape, SEMA I, 30/XI/2002, fl., R.N.A. Brasil et al. 206 (JPB); SEMA II, Cabeça de Boi, 11/II/2010, fr., M.R. Barbosa et al. 3293 (JPB). Rio Tinto, SEMA III, Mata do Maracujá, 27/IV/199o, fl. e fr., L.P. Félix E E.S. Santana 2956 (JPB).

Espécie com ampla distribuição no Brasil (Goldenberg 2012) é comumente encontrada na ReBio Guaribas em áreas de savana em solos arenosos. Miconia albicans pode ser identificada pelas folhas de margem inteira, nervuras basais, flores com anteras brancas, organizadas em panículas com ramos secundifloros.

8. Miconia amoena Triana, Trans. Linn. Soc. London 28 (1): 115. 1871.

(Fig. 2 B)

Arbusto de 1-3,5 m alt.; ramos compressos; tricomas estrelados, lepidotos e capitados. Folhas pecioladas; pecíolo 1,5-3 cm compr.; lâmina 3,5-15 x 6,6-8 cm, obovada a elíptica, cartácea, ápice abruptamente agudo a obtuso, margem inteira, base aguda, face adaxial glabra e abaxial densamente lanosa, com tricomas lepidotos e capitados esparsos; nervuras 3-5, basais. Panícula com ramos espiciformes, glomerulares, 1014,6 cm compr., terminal, com ramos acessórios. Flor 5-mera, séssil; hipanto 4-5 mm compr., infundibuliforme; cálice persistente; pétalas 5-6 x 2-2,5 mm, alvas, glabras, ápice truncado a emarginado, base cuneada; estames-10, glabros; anteras 2,3-3,3 mm compr., poricidas, alvas, curvas, antepétalas com apêndice 2-lobado e antessépalas sem apêndices; ovário 1,5-2 mm compr., 3-4-locular, ápice papiloso; estilete 7-8 mm compr., piloso a glabro, ápice cilíndrico. Baga 4-6 mm compr., urceolada, imatura verde, atropurpúrea na maturidade; sementes 2-2,5 mm compr., ovais. 
Material selecionado: BRASIL. Paraíba: Mamanguape, SEMA II, 11/II/2010, bot., fl. e fr., M.R. Barbosa et al. 3292 (JPB); Caiana, 2/II/2003, fl., M.R.Barbosa et al. 2649 (JPB). Rio Tinto, SEMA III, III/2011, Chagas-Mota 10316 (JPB, NY).

Miconia amoena é endêmica da Mata Atlântica brasileira (Goldenberg 2012) e pode ser encontrada na ReBio Guaribas em savanas sobre solos arenosos. Esta é a única espécie que apresenta lâmina com face abaxial completamente revestida por indumento, inflorescência ou infrutescência com ramos espiciformes, e flores e frutos reunidos em glomérulos.

9. Miconia ciliata (Rich.) DC., Prodr. 3: 179. 1828.

(Fig. 2 C-D)

Arbusto $2 \mathrm{~m}$ alt.; ramos cilíndricos; tricomas simples. Folhas pecioladas; pecíolo o,5-5 cm compr.; lâmina 8-18,2 x 2,8-8 cm, oblongo-elíptica a ovada, membranácea, ápice acuminado, margem ciliada, base obtusa a aguda, face adaxial glabra e abaxial puberulenta a glabra; nervuras 3-5, as laterais confluentes, basais. Panícula com ramos secundifloros, 4,5-10,5 cm compr., terminal; bractéolas persistentes. Flor 5-mera, séssil; hipanto 2-2,3 $\mathrm{mm}$ compr., urceolado, glabro ou com tricomas esparsos; cálice decíduo; pétalas 2-2,5 x 1-1,5 mm, róseas, oblongas, glabras, ápice truncado a emarginado; estames-10, glabros; anteras 1,25-2 mm compr., poricidas, róseas, retas, conectivo sem apêndice; ovário 1-2 mm compr., 3-4-locular, ápice glabro; estilete 2-2,5 mm compr., glabro, ápice cilíndrico. Baga 3,5-4 mm compr., urceolada, imatura verde, atropurpúrea na maturidade; sementes o,5-o,8 mm compr., ovais.

Material selecionado: BRASIL. Paraíba: Mamanguape, SEMA II, 27/V/2002, fl., fr., R.N.Brasil et al. 6o (JPB); SEMA I, Capim Azul, 15/XII/2009, fl., fr., W.W.Thomas et al. 15040 (JPB).

Esta espécie possui ampla distribuição no Brasil, exceto em alguns estados da região sudeste e sul do Brasil (Goldenberg 2012). Miconia ciliata pode ser facilmente identificada pela presença de lâminas com margem ciliada. Na ReBio Guaribas é encontrada junto à nascentes ou cursos de rios e riachos.

10. Miconia cuspidata Naudin, Ann. Sci. Nat., Bot., ser. 3, 16 (2): 163.1850.

(Fig. 2 E)

Arbusto ou árvore 2,5-10 m alt.; ramos cilíndricos; tricomas estrelados. Folhas pecioladas; pecíolo o,5-1,5 cm compr.; lâmina 8-11 x 1,6-2,4 cm, oblongo-lanceolada, membranácea a cartácea, ápice cuspidado a aristado, margem repanda a inteira, base obtusa, face adaxial glabra e abaxial puberulenta a glabra com domácias na base; nervuras 3-5, basais. Panícula com ramos dicasiais, 4,5-9,6 cm compr., terminal. Flor 5-mera; pedicelo 2-4.1 mm compr.; hipanto 2-3 mm compr., urceolado; cálice decíduo; pétalas 2,2-3,5 x 2-2,5 mm, alvas, oblanceoladas, papilosas, ápice obtuso a 
emarginado; estames-10, glabros; anteras 2-3,5 mm compr., poricidas, alvas, retas, apêndice 3-lobado; ovário 1-2 mm compr., 3-locular, ápice papiloso; estilete 3,5-4,5 mm compr., glabro, ápice clavado. Baga 4-6 mm compr., globosa, imatura verde, atropurpúrea na maturidade; sementes o,5-1,5 mm compr., ovais.

Material examinado: BRASIL. Paraíba: Mamanguape, SEMA II, 21/VII/2010, fl., Chagas-Mota et al. 7854 (JPB, NY); 28/IX/2010, fl., Chagas-Mota et al. 8710 (JPB).

Material adicional examinado: BRASIL. Paraíba: Sapé, 16/VIII/2010, fl. e fr., Chagas-Mota 8o6o (MAC).

Miconia cuspidata possui maior distribuição na região amazônica, sendo raramente coletada na Mata Atlântica (Goldenberg 2012). Na ReBio Guaribas, habita áreas florestadas e pode ser confundida com M. minutiflora, porém apresenta domácias na base da lâmina. Este é o primeiro registro da espécie para o estado da Paraíba.

11. Miconia ferruginata DC., Prodr. 3: 181. 1828.

(Fig. 2 F)

Arbusto 15-25 m alt.; ramos quadrangulares; tricomas estrelados sésseis e estreladoestipitados. Folhas pecioladas; pecíolo o,7-1,4 cm compr.; lâmina 10,8-29,7 x 5-11,3 $\mathrm{cm}$, lanceolada, coriácea, ápice agudo a obtuso, margem repanda a inteira, base aguda a obtusa, face adaxial glabra e abaxial pubescente a glabrescente; nervuras 3-7, basais. Panícula com ramos secundifloros, 16,5-22,3 cm compr., terminal. Flor 5-mera, séssil; hipanto 2,5-3 mm compr., campanulado; cálice persistente; pétalas 3,5-4,5 X 2-2,5 mm, alvas, obovadas, glabras, ápice obtuso a emarginado; estames-10, glabros; anteras 2,8-4,3 mm compr., poricidas, alvas, retas, antepétalas com apêndice 3-lobado, antessépalas com apêndice inteiro; ovário 2-3 mm compr., 3-locular, ápice papiloso; estilete 5-8 mm compr., glabro, ápice cuneado. Baga 8,5-11 mm compr., globosa, imatura verde, atropurpúrea na maturidade; sementes 1-1,5 mm compr., ovais.

Material examinado: BRASIL. Paraíba: Mamanguape, SEMA II, 21/VII/2010, fr., Chagas-Mota 7857 (JPB, NY).

Miconia ferruginata é uma espécie pouco comum em áreas de Mata Atlântica do Nordeste. Foi encontrada somente uma pequena população de cinco indivíduos à margem de uma estrada na ReBio Guaribas, em área de savana. Este é o primeiro registro da espécie para o estado da Paraíba. 
12. Miconia minutiflora (Bonpl.) DC., Prodr. 3: 189. 1828.

(Fig. $2 \mathrm{G}$ )

Arbusto ou árvore 5-8 m alt.; ramos cilíndricos; tricomas estrelados. Folhas pecioladas; pecíolo o,6-1,3 cm compr.; lâmina 8,5-14 x 3-5 cm, oblongo-elíptica a elíptico-lanceolada, membranácea, ápice caudado a mucronado, margem repanda a inteira, base aguda a obtusa, face adaxial glabra e abaxial glabrescente, sem domácias, com tricomas somente sobre as nervuras; nervuras 3-5, basais. Panícula com ramos dicasiais, 5,3-18,8 cm compr., terminal ou lateral, com ramos acessórios. Flor 5-mera; pedicelo 1-2 mm compr.; hipanto 1,5-2 $\mathrm{mm}$ compr., urceolado; cálice decíduo; pétalas 2-2,5 x 1-1,25 mm, alvas, oblanceoladas, glabras; estames-10, glabros, ápice obtuso a emarginado; anteras 1-1,75 mm compr., poricidas, alvas, retas, antepétalas com apêndice 3-lobado, antessépalas com apêndice 1-lobado; ovário 0,5-1 mm compr., 3-locular; estilete 2-3 mm compr., glabro, ápice clavado. Baga 4-5 mm compr., globosa, imatura verde, atropurpúrea na maturidade; sementes o,5-1 mm compr., ovais.

Material selecionado: BRASIL. Paraíba: Mamanguape, Trilha do Poste de Cimento, 26/VII/2010, fl., R.A. Pontes et al. 492 (JPB); 12/VIII/2011, fl., R.A.Pontes E R.C.Duré 750 (JPB).

Miconia minutiflora possui ampla distribuição geográfica, habitando áreas florestais, ao longo de cursos de rios e córregos. Pode ser identificada pela presença de lâmina foliar não decorrente no pecíolo com face abaxial glabra ou glabrescente e nervuras basais sem domácias.

13. Miconia prasina (Sw.) DC., Prodr. 3: 188. 1828.

(Fig. $2 \mathrm{H}$ )

Arbusto ou árvore $3 \mathrm{~m}$ alt.; ramos cilíndricos; tricomas estrelados. Folhas pecioladas; pecíolo o,6-1 cm compr.; lâmina 12,2-23 x 4,5-7 cm, elíptica, membranácea, ápice agudo a aristado, margem denticulada com tricomas glandulosos, base atenuada, decurrente, face adaxial glabra e abaxial pubescente ou com tricomas somente sobre as nervuras, sem domácias; nervuras 3-5, suprabasais. Panícula com ramos dicasiais, 7-10 cm compr., terminal, com ramos acessórios; bractéolas persistentes. Flor 5-mera; pedicelo o,5-1 $\mathrm{mm}$; hipanto 2,5-3 $\mathrm{mm}$ compr., campanulado; cálice persistente; pétalas 1,5-3 x 1-2 mm, alvas, oblongas, papilosas, ápice obtuso a emarginado; estames-10, glabros; anteras 2-3 mm compr., poricidas, alvas, curvas, apêndice 2-lobado; ovário 1-1,5 mm compr., 3-4-locular, ápice papiloso; estilete 1-2 mm compr., glabro, ápice levemente expandido. Baga 4,5-7 mm compr., globosa, imatura verde, atropurpúrea na maturidade; sementes o,5-1 mm compr., ovais. 
Material selecionado: BRASIL. Paraíba: Mamanguape, SEMA II, 31/II/1989, fl., L.P. Félix E E.S. Santana s.n. (JPB 8083). Rio Tinto, SEMA III, 15/XII/2009, bt., W.W. Thomas et al. 15027 (JPB).

Miconia prasina possui ampla distribuição geográfica, ocorrendo na ReBio Guaribas em terrenos próximos a rios e córregos, em áreas florestadas ou savanas. Pode ser facilmente reconhecida pela presença de lâmina decurrente no pecíolo.

14. Miconia serialis DC., Prodr. 3: 182. 1828.

Fig. 2 I)

Arbusto ou árvore 0,5-7 m alt.; ramos cilíndricos; tricomas aracnóides. Folhas pecioladas; pecíolo o,9-2,3 cm compr.; lâmina 10-24,5 X 3-6,2 cm, oblongo-lanceolada, cartácea a coriácea; ápice agudo a aristado, margem inteira, base auriculada, face adaxial glabra e abaxial lanosa; nervuras 3-5, as laterais confluentes, suprabasais. Panícula com ramos secundifloros, 5,5-20,6 cm compr., terminal; bractéolas decíduas. Flor 5-mera, séssil; hipanto 2-3 mm compr., campanulado; cálice persistente; pétalas 2,5-3 x 2-2,5 mm, alvas, orbiculadas, glabras, ápice obtuso a emarginado, glandularciliada na margem ou não; estames-10, glabros; anteras 2-4,5 mm compr., poricidas, alvas, retas, antepétalas com apêndice 3-lobado, antessépalas com apêndice inteiro; ovário 1-2 mm compr., 3-locular, ápice papiloso; estilete 4-6 $\mathrm{mm}$ compr., glabro, ápice cuneado. Baga 3-6 mm compr., globosa, imatura verde, verde ou amarela na maturidade; sementes 1-1,5 mm compr., ovais.

Material examinado: BRASIL. Paraíba: Mamanguape, SEMA II, 21/VII/2011, fr., Chagas-Mota 7856 (JPB).

Material adicional examinado: BRASIL. Alagoas: Maceió, 27/XII/20oo, fl., $R$. Lemos E E. Santos 5218 (MAC).

Esta espécie é muito confundida com M. albicans, entretanto os indivíduos de M. serialis são arbóreos (vs. arbustivos), possuem nervuras suprabasais (vs. basais) e ápice do estigma cuneado (vs. ápice capitado). Na ReBio Guaribas habita áreas florestadas, com solos arenosos. Este é o primeiro registro da espécie para o estado da Paraíba.

15. Miconia stenostachya DC., Prodr. 3: 181. 1828.

(Fig. $2 \mathrm{~J}$ )

Arbusto 2-3 m alt.; ramos cilíndricos; tricomas aracnóides. Folhas sésseis ou pecioladas; pecíolo o,2-1 cm compr.; lâmina 10-13 x 5-7 cm, elíptico-lanceolada, coriácea, ápice aristado a emarginado, margem inteira, base cordada, face adaxial glabra e abaxial lanosa; nervuras 3-5, basais. Panícula com ramos secundifloros, 9,5- 
$18 \mathrm{~cm}$ compr., terminal; bractéolas persistentes. Flor 5-mera, séssil; hipanto 2-25 mm compr., campanulado; cálice persistente; pétalas 4-4,5 x 3-3,5 mm, alvas, elípticas, papilosas, ápice obtuso a emarginado, glandular-ciliadas na margem; estames-10, glabros; anteras 3-4,5 mm compr., poricidas, amarelas ou vermelhas, retas, antepétalas com apêndice 3-lobado, antessépalas com apêndice 1-lobado; ovário 2-2,5 mm compr., 3-locular, ápice papiloso; estilete 7-9 mm compr., piloso, ápice truncado. Baga 7-10 mm compr., globosa, imatura rosa, atropurpúrea na maturidade; sementes 1-1,5 mm compr., ovais.

Material selecionado: BRASIL. Paraíba: Mamanguape, SEMA II, Caiana, 2/ II/2003, fl. e fr, M.R. Barbosa et al. 2648 (JPB). Rio Tinto, SEMA III, Mata do Maracujá, 20/XII/1989, fl., L.P.Félix E E.S.Santana 2596 (JPB);

Miconia stenostachya pode ser confundida com M. albicans, da qual se diferencia pelas anteras amarelas ou vermelhas (vs. alvas em M. albicans), apêndice do conectivo 1-lobado ( $v s$. inteiro ou 3-lobado), frutos imaturos verdes (vs. róseos) e atropurpúreos na maturidade (vs. verdes). Na ReBio pode ser encontrada em áreas de savana, com solos arenosos.

16. Miconia tomentosa (Rich.) D.Don ex DC., Prodr. 3: 183.1828.

Fig. $2 \mathrm{~K}$ )

Árvore $15 \mathrm{~m}$ alt.; ramos cilíndricos; tricomas estrelados e dendríticos. Folhas sésseis ou pecioladas; pecíolo o,5-1 cm compr.; lâmina 23-45 x 11-18,8 cm, elíptica a obovada, membranácea; ápice caudado a aristado, margem repanda a inteira, base atenuada, face adaxial glabra e abaxial tomentosa; nervuras 3-5, suprabasais. Panícula com ramos dicasiais, 20-25 cm compr., terminal. Flor 5-mera; pedicelo 1-2 mm compr.; hipanto 1,5-2 mm compr., tubular; cálice persistente; pétalas 9-11 x 4-6 mm, pardas, cuneadas, papilosas, ápice truncado a emarginado; estames-10, pilosos; anteras 6-11 mm compr., poricidas, lilases, curvas, apêndice 2-lobado com glândulas pediceladas; ovário 3-4 mm compr., 4-locular, ápice piloso; estilete 9-11 $\mathrm{mm}$ compr., piloso, ápice truncado. Baga 9-12 mm compr., urceolada, imatura verde, atropurpúrea na maturidade; sementes 1-1,5 mm compr., ovais.

Material examinado: BRASIL. Paraíba: Rio Tinto, SEMA III, Mata do Maracujá, 15/XII/2009, fr., W.W.Thomas et al. 15028 (JPB).

Material adicional examinado: BRASIL. Pernambuco: Igarassu, Usina São José, 19/XI/2010, fl., Chagas-Mota 9494 (JPB, MAC, UFP).

Miconia tomentosa é uma espécie pouco frequente que habita as raras matas ciliares remanescentes na região Nordeste, sendo apontada como ameaçada de 
extinção segundo os critérios da IUCN (2012). Pode ser reconhecida pelas grandes folhas sésseis $(23-45 \mathrm{~cm})$, filetes pilosos e glândulas no apêndice do conectivo.

17. Nepsera aquatica (Aubl.) Naudin, Ann. Sci. Nat., Bot. sér. 3, 13: 28.1850. (Fig. 2 L-M)

Subarbusto 0,5-1 m alt.; ramos angulosos, avermelhados; tricomas simples, esparsos. Folhas pecioladas; pecíolo o,5-1 cm compr.; lâmina 3-5,5 x 1,3-2,5 cm, ovada a elíptica, membranácea, ápice agudo, margem serreada, base obtusa a truncada, ambas as faces glabras; nervuras 5-7, as laterais confluentes, basais. Panícula 9,5-14 x 8-10,5 cm, axilar ou terminal. Flor 4-mera, pedicelo ca. $1 \mathrm{~mm}$ compr.; hipanto ca. 2,5 x 2,5 $\mathrm{mm}$, globoso, glabro; cálice persistente, lacínios 2-2,2 x 0,9-1 mm, deltoides, ápice agudo; pétalas 4,5-5 x 2-2,5 mm, alvas, elípticas, glabras, ápice agudo; estames-8, glabros; anteras 2,2-2,8 $\mathrm{mm}$ compr., poricidas, roxas, retas, conectivo abaixo das anteras ca. o,4 mm compr., apêndice ventral o,3-0,4 mm compr., bilobado; ovário ca. 2 × 2 mm, 4-locular, ápice glabro; estilete ca. $7 \mathrm{~mm}$ compr., glabro. Cápsula ca. 1,5 mm compr., globosa, imatura verde, creme na maturação; sementes o,4-o,6 mm compr., cocleares.

Material selecionado: BRASIL, Paraíba: Mamanguape, SEMA II, Cabeça de Boi, 31/VIII/1989, fl. e fr., L.P. Félix E E.S. Santana 2195 (JPB).

Nepsera aquatica ocorre nas regiões Norte e Nordeste do Brasil (Baumgratz 2012). Em Guaribas a espécie foi encontrada em áreas de florestas, distinguindo-se por seus ramos avermelhados, hipanto glabro, pétalas alvas e anteras roxas.

18. Pterolepis glomerata (Rottb.) Miq., Comm. Phytogr. 2: 78. 1840.

(Fig. 2 N-O)

Erva 20-40 cm alt.; ramos angulosos; tricomas simples, não glandulosos. Folhas pecioladas; pecíolo 1-2 mm compr.; lâmina 1,1-2,3 x 0,5-1 cm, lanceolada a largamente lanceolada, membranácea; ápice agudo, margem crenado-ciliada, base aguda, ambas as faces seríceas; nervuras 3, as laterais confluentes, basais. Dicásios axilares ou terminais. Flor 4-mera, pedicelo 1,5-2 mm compr.; hipanto 2,2-3,5 x 2,5-3 mm, globoso, tricomas ramificados, não glandulosos; cálice persistente, lacínios 4-4,2 X 2,5-3 mm, deltoides, ápice agudo; pétalas 10-12 x 7-10 mm, róseas, obovais, glandularciliadas, ápice arredondado; estames-8, glabros; anteras 2,5-3,8 mm compr., poricidas, amarelas com metade distal lilás nos estames antessépalos e totalmente amarelas nos antepétalos, retas, conectivo não prolongado, apêndice ventral o,4-0,5 mm compr., bituberculado; ovário ca. 3 x $4 \mathrm{~mm}$, 4-locular, ápice piloso, não glanduloso; estilete ca. 7 mm compr., glabro. Cápsula 3-4 mm compr., globosa, imatura verde, castanha na maturação; sementes o,2-0,3 mm compr., cocleares. 
Material examinado: BRASIL, Paraíba: Mamanguape, SEMA II, Cabeça de Boi, o1/II/1989, bt., L.P. Félix E E.S. Santana s.n. (JPB 8087).

Material adicional examinado: BRASIL, Paraíba: Conde, APA Tambaba, Vale do Bucatu, o6/XI/2009, fl. e fr., C.M.L.R. Araújo et al. 190 (JPB).

Pterolepis glomerata é uma espécie de distribuição ampla, ocorrendo em todas as regiões do país (Romero 2012). Na ReBio Guaribas, até o presente momento, este foi o único registro da espécie, que foi encontrada na borda do fragmento de floresta. Distingue-se das demais espécies de Melastomataceae registradas na área por apresentar lâmina foliar lanceolada e pelas anteras dos estames antessépalos amarelas com metade distal lilás.

19. Pterolepis trichotoma (Rottb.) Cogn., Fl. Bras. 14(3): 261-262. 1885.

(Fig. 2 P-Q)

Ervas $15-20 \mathrm{~cm}$ alt.; ramos angulosos; tricomas simples, não glandulosos. Folhas pecioladas; pecíolo 2-3 mm compr.; lâmina 2,2-4,6 x 1-2,6 cm, ovada, membranácea; ápice agudo, margem serreada, ciliada, base obtusa, ambas as faces seríceas; nervuras 3-5, as laterais confluentes, basais. Dicásios ou flores solitárias, axilares ou terminais. Flor 4-mera, pedicelo 1-2 mm compr.; hipanto 2,2-2,5 x 1,5-2 mm, oblongo, tricomas ramificados, glandulosos ou não; cálice persistente, lacínios 1,5-1,8 x 1-1,2 mm; pétalas 3-4 X 2,5-3 mm, lilases, obovadas, glandular-ciliadas, ápice obtuso; estames-8, glabros; anteras 1,8-2,5 mm compr., poricidas, roxas ou lilases com ápice alvo, retas, conectivo não prolongado com apêndice ventral o,2-0,5 mm compr., bilobado; ovário 2 x 1,5 $\mathrm{mm}$, 4-locular, ápice piloso; estilete ca. 6,5 mm compr., glabro. Cápsula 3-4 x 2-3 $\mathrm{mm}$ compr., globosa, imatura verde, castanha na maturação; sementes 0,2-0,3 mm compr., cocleares.

Material examinado: BRASIL, Paraíba: Mamanguape, SEMA II, Cabeça de Boi, 31.VIII.1989, fl., L.P. Félix E E.S. Santana 2223 (JPB).

Material adicional examinado: BRASIL, Paraíba: Santa Rita, BR 230, Km 48, 18.VIII.2011, fl. e fr., L.A. Pereira E J.C. Silva 277 (JPB).

Pterolepis trichotoma ocorre nas regiões Norte, Nordeste, Centro-Oeste e Sudeste do Brasil (Romero 2012). Em Guaribas, até o presente momento, este é o único registro da espécie para a área, que foi encontrada na mata. Pode ser caracterizada por apresentar lâmina foliar ovada e anteras lilases com ápice branco. Este é o primeiro registro da espécie para o estado. 
20. Trembleya phlogiformis DC., Prod. (DC.) 3: 126.1828.

(Fig. 2 R)

Arbusto, ca. $2 \mathrm{~m}$ alt.; ramos cilíndricos; tricomas hirsuto-glandulosos. Folhas pecioladas; pecíolo 0,1-0,5 cm compr.; lâmina 4,8-5,2 x 1,2-1,5 cm, lanceolada, membranácea a cartácea; ápice agudo, margem serreada, ciliada, base aguda a obtusa, face adaxial glabra e abaxial pilosa; nervuras $5^{-7}$, as laterais confluentes, basais. Panícula 8,5-10 x 2,5-7 cm axilar. Flor 5-mera, pedicelo o,1-0,7 cm compr.; hipanto 2,5-3 x 1,5-2 mm compr., urceolado, piloso-glanduloso; cálice persistente, lacínios 1,1-3 x 0,5-1 mm, triangulares; pétalas 4-9 x 2-5 mm, róseas, obovadas, glabras, ápice agudo; estames-10, glabros; anteras 2-4 mm compr., poricidas, lilases, ovoideoblongas, retas, conectivo 1,1-1,5 mm compr., apêndice ventral ca. 0,5 mm compr., bilobado; ovário 1,5-2 x 1-1,5 mm, 5-locular, ápice glabro; estilete ca. 7,5-11 mm compr., glabro. Cápsula 5-7 mm compr., globosa, imatura verde, castanha na maturação; sementes o,9-1,1 mm compr., ovoides.

Material examinado: BRASIL, Paraíba: Rio Tinto, SEMA III, Mata do Maracujá, 23/V/1990, fl. e fr., L.P. Félix E E.S. Santana 3024 (JPB 18502).

Trembleya phlogiformis é considerada uma espécie de ampla distribuição, ocorrendo em todo o território brasileiro (Martins \& Bernardo 2012). Este é, até o momento, o único registro do gênero para o estado da Paraíba. Há, segundo dados disponiveis no CRIA (2012), registros do gênero, para a Bahia, Ceará e Pernambuco, sendo que para o Ceará existe uma única coleta oriunda do município de Granja. Distingue-se das demais espécies da família encontradas na área pelos ramos com tricomas hirsuto-glandulosos, lâmina foliar lanceolada e anteras ovóide-oblongas.

\section{AGRADECIMENTOS}

Os autores agradecem aos curadores dos herbários consultados e ao Dr. William Wayt Thomas pelas correções e revisão do abstract. Ao CNPq pelo apoio financeiro através do Programa de apoio à Taxonomia (PROTAX). A National Science Foundation (NSF)/USA, Velox Stiftung e Beneficia Foundation pelo financiamento ao Projeto "Diversidade Florística, Conservação e Limites da Floresta Atlântica no Nordeste do Brasil”. A todos da Reserva Biológica Guaribas pelo apoio e ao Ministério do Meio Ambiente pela licença para pesquisa. 


\section{REFERÊNCIAS}

BAUMgratZ, J. F. A. Comolia in Lista de Espécies da Flora do Brasil. Jardim Botânico do Rio de Janeiro. Disponível em: <http://floradobrasil.jbrj.gov.br/2012/ FBo85242>. Acesso em: 20 set. 2012.

BAUMgratZ, J. F. A. Nepsera in Lista de Espécies da Flora do Brasil. Jardim Botânico do Rio de Janeiro. Disponível em: <http://floradobrasil.jbrj.gov.br/2012/ FBoog827>. Acesso em: 20 set. 2012.

COGNIAUX, C. A. 1891. Melastomataceae. Pp. 1-1256. In: CANDOLLE, A. de.; CANDOLLE, C. de. Monographie Phanerogamarum. Paris: Masson, 1891. v. 7, p. 1-1256.

COGNIAUX, C. A. Melastomataceae. In: MARTIUS, C. F. P.; EICHLER, A. G. Flora Brasiliensis. Fleischer: Leipzig, 1883-1888. v. 14, p. 1-655.

GOLDENBERG, R. Miconia in Lista de Espécies da Flora do Brasil. Jardim Botânico do Rio de Janeiro. Disponível em: <http://floradobrasil.jbrj.gov.br/2012/FBoo9750>. Acesso em: 17 ago. 2012.

IUCN IUCN Red List of Threatened Species. Version 2012.1. Disponível em: <www. iucn.org>. Acesso em: 17 ago. 2012.

MARTINS, A. B.; BERNARDO, K. F. R. Marcetia in Lista de Espécies da Flora do Brasil. Jardim Botânico do Rio de Janeiro. Disponível em: <http://floradobrasil.jbrj. gov.br/2012/FBoog647>. Acesso em: 20 set. 2012.

MARTINS, A. B.; BERNARDO, K. F. R. Trembleya in Lista de Espécies da Flora do Brasil. Jardim Botânico do Rio de Janeiro. Disponível em: <http://floradobrasil.jbrj. gov.br/2012/FBoog985>. Acesso em: 20 set. 2012.

MATSUMOTO, K.; MARTINS, A.B. Melastomataceae nas formações campestres do município de Carrancas, Minas Gerais. Hoehnea 32(3):389-420. 2005.

MICHELANGELI, F. A.; REGINATO, M. Clidemia in Lista de Espécies da Flora do Brasil. Jardim Botânico do Rio de Janeiro. Disponível em: <http://floradobrasil.jbrj. gov.br/2012/FBoo9444>. Acesso em: 20 set. 2012.

ROMERO, R. Pterolepis in Lista de Espécies da Flora do Brasil. Jardim Botânico do Rio de Janeiro. Disponível em: <http://floradobrasil.jbrj.gov.br/2012/FBoog859>. Acesso em: 20 set. 2012. 
SPECIES LINK. Disponível em: < http://www.splink.org.br>. Acesso em: 3 jun. 2012.

WURDACK, J. J.; RENNER, S. S.; MORLEY, T., Melastomataceae. 1993. Pp.161-258. In: Flora of the Guianas. Phanerogams, koenisgstein: van Rijn, A.R.A.G. Koeltz Scientific Books, Vol. 13. 